\title{
Edinburgh, St Giles, Percival Pott and Paraplegia ${ }^{\star}$
}

\author{
Abraham Ohry, ${ }^{1}$ M.D. and Karin Ohry-Kossoy, M.A. \\ ${ }^{1}$ Sir Ludwig Guttmann Spinal Cord Injury Center, Rehabilitation Center, Chaim \\ Sheba Medical Center, Tel-Hashomer and Sackler School of Medicine, Tel-Aviv \\ University, Israel
}

'From scenes like these, old Scotia's grandeur springs that makes her loved at home, revered abroad'.

Robert Burns (1759-1796)

The Cotter's Saturday Night, 1786.

On the occasion, when the Scientific Meeting of the International Medical Society of Paraplegia took place in Edinburgh, several associations came to my mind. One was St Giles, or Egidus, who was born in 725 A.D. Giles is the patron saint of Edinburgh and also, among others, of cripples, lepers and beggars. $\mathrm{He}$ was an Athenian prince who was revered for his miraculous gifts. He healed a sick man, whom he had found in a church, by laying his cloak over him. Fearing danger to his soul from the fame which resulted from this miracle, he withdrew to a solitary cave in the South of France, near Nimes. There he lived as a hermit, nourished only by wild herbs and the milk of a doe which had followed him.

One day the King of France, Flavius the Goth, hunting nearby, shot the doe and, pursuing it, came upon the aged hermit, holding the doe in his arrow-pierced hand. The King, seeing that Giles was a man of God, begged forgiveness and tried to convince the hermit to come with him. But Giles refused to leave his retreat and remained in the cave until his death. The place became sacred, and a church and a monastery were built there in his honour, as well as the town of St Giles (Greene, 1911). In art St Giles is characterized by an arrow transfixing his breast or hand. His holiday was celebrated only four days ago, on September the 1st. His cult was made popular here by homecoming Crusaders, who had learned to worship him while staying in the South of France. In Great Britain alone over 150 churches are dedicated to him, among them St Giles Cripplegate in London, and the High Kirk in Edinburgh. In the days when medicine offered little or no relief from suffering, when the 'cure was often worse than the disease

« Read at the Scientific Meeting of the International Medical Society of Paraplegia, Edinburgh, Scotland. September 1985.

Address for correspondence: Abraham Ohry, M.D., Rehabilitation Center, Chaim Sheba Medical Center, Tel-Hashomer 52621, Israel. 
and when people believed in God, they said their prayers to the saints in a hope of cure' (Dewhurst, 1981).

Several centuries later, in Shakespeare's time, the situation was not much better. His 37 plays bear witness to a profound knowledge of contemporary medicine and indeed he mentions all the diseases and drugs that were known in those times. Yet (as in 'Macbeth'), doctors had to admit that remedy was beyond their capabilities: 'this disease is beyond my practice' (Macbeth, V, i, 57). Two physicians, one English and one Scottish, are presented in the play. Macbeth, apart from his other characteristics, is an epileptic, and has several fits during the tragedy. The English doctor is consulted, and speaks of the miraculous healing powers that kings were supposed to exert by touching. He believes in witchcraft, and gives a good description of quackery, which must have been widespread then (Kail, 1983). The doctor says:

'There are a crew of wretched souls

that stays his cure. Their malady convinces

The great assay of art, but at his touch

Such sanctity hath heaven given his hand

They presently amend' (IV, iii, 141).

A dark, mystical aspect of the play is symbolized by the three witches, one of whom was traditionally shown walking with canes or crutches. And Macbeth, the Scottish hero of the tragedy, says:

'Throw physic to the dogs-

I'll none of it' (V, iii, 47).

We now move from these legendary stories to the modern era, when Scottish physicians and surgeons deeply influenced medicine.

The Englishman Marshall Hall is famous for having formulated the concept of 'the reflex function of the medulla oblongata and medulla spinalis' (1833). But in fact, before him, it was Robert Whytt of Edinburgh who showed that destruction of the anterior optic lobe abolishes the contraction of the pupil to light (Whytt's reflex), and that a mere fragment of the spinal cord will suffice for the maintenance of reflex movements.

Famous Scottish surgeons, such as Robert Liston, James Syme, and Sir William Fergusson are still frequently mentioned in orthopaedic rehabilitation wards. Sir Charles Bell (of Edinburgh), who discovered, parallel to Magendie, the difference between sensory and motor nerves, was a leading anatomist and surgeon in his time. He and his brother, John (1763-1820) both had an uncommon artistic gift, and they themselves illustrated their own medical or surgical books. Very relevant to us here, Sir Charles wrote in 1811 about 'a new idea of the anatomy of the brain and nervous system': 'on laying bare the roots of the spinal nerves, I found that I could cut across the posterior fasciculus of nerves which took its origin from the posterior position of the spinal marrow without convulsing the muscles of the back, but that on touching the anterior fasciculus with the point of the knife, the muscles of the back were immediately convulsed'.

I shall end these medico-historical associations with Percival Pott (of London), who published his epoch-making pamphlet on 'palsy from spinal deformity' 
(caries) in 1779. Pott's work on 'tuberculous paraplegia' was published while he was working at St Bartholomew's Hospital, but in 1786 the Royal College of Surgeons of Edinburgh gave Pott a Honorary Fellowship for this work. Next year will mark the 200th anniversary of this event.

\section{References}

Dewhurst J (1981) Jest with saints: Second opinion. Lancet 2:573-574.

GREENE EA (1911) Saints and their symbols. 26th impression. London, Whittaker.

KAIL AC (1983) Shakespeare's physicians. Med J Aust 2:338-344.

SEIBER J (1977) The urban saints in early Byzantine social history. British Archeological Reports, Suppl. Series, 37. 